\title{
Religijne wychowanie dziecka w sytuacji rozwodu rodziców
}

Współcześnie rozwód jest zjawiskiem powszechnym. Szczególnie ważki jest problem dziecka w obliczu rozwodu rodziców, obrazują to dane statystyczne. Małoletnich dzieci pozostających z małżeństw rozwiedzionych w 2012 roku było $54026^{1}$, w latach 2011 i 2010 było to odpowiednio $54104^{2}$ i 52165 dzieci3 $^{3}$. W roku 2012 sądy podjęły 37570 decyzji w sprawie powierzenia władzy rodzicielskiej nad małoletnim (decyzje te dotyczyły nie tylko małżeństw). W 22690 przypadkach sąd powierzył władzę rodzicielską i opiekę nad dzieckiem matce, matce i ojcu wspólnie w 12503 wyrokach, wyłącznie ojcu w 1643, oddzielnie ojcu i matce - w 323; inne przypadki to 411 orzeczeń4. Według danych GUS w roku 2011 katolicy stanowili 95,5 proc. ludności Polski5. Jeśli przyjmiemy stosunek liczby katolików

\footnotetext{
1 „Rocznik Demograficzny” 2013, s. 278.

2 "Rocznik Demograficzny” 2012, s. 254.

3 „Rocznik Demograficzny” 2011, s. 234.

4 „Rocznik Demograficzny” 2013, s. 280.

5 GUS, Wyznania religijne, stowarzyszenia narodowościowe $i$ etniczne w Polsce 2009-2011, Warszawa 2013, s. 36. Według „Rocznika Statystycznego” z 2012 roku 86,88 proc. społeczeństwa to katolicy, przy czym liczba ludności wyniosła 38512 ooo, s. 188 i s. 212.
} 
w Polsce do liczby dzieci pozostających z małżeństw rozwiedzionych w 2011 roku, to szacunkowo liczba katolickich dzieci rozwodzących się rodziców wynosi około 47 tysięcy.

Rozwód przynosi problemy wielopłaszczyznowe, a zmiany przez nie wprowadzane dotyczące struktury rodziny zmieniają sposób realizowania funkcji wychowawczej. Problematyka ta jest sprawą zarówno państwa, jak i Kościoła, ponieważ integralny rozwój dziecka należy do obszaru zainteresowania obojga prawodawców. Celem artykułu jest ukazanie wpływu polskich regulacji prawnych i kanonicznych regulacji prawnych Kościoła katolickiego na wychowanie religijne dziecka w sytuacji ustania małżeństwa rodziców dziecka przez rozwód.

\section{Kontekst wychowania dziecka}

Rodzina jest specyficzną grupą społeczną, która łączy cechy wspólnoty i zrzeszenia. Oznacza to, że jej właściwości opierają się z jednej strony na naturze ludzkiej, na wyjątkowych więziach opartych na dobrowolności, wspólnym dążeniu do celu. Równocześnie jest ona ujęta w strukturę prawną, regulującą wzajemne prawa i obowiązki wewnątrzrodzinne członków, jak i te wynikające z relacji zewnętrznych rodzinno-społecznych. Uznaje się też, że jest ,jedyną grupą zbudowaną na miłości, gdzie prawo interweniuje wyjątkowo dla umocnienia więzów wspólnoty”. Relacje w rodzinie podlegają ochronie ze strony prawodawcy zainteresowanego jej właściwym funkcjonowaniem, w tym wychowaniem potomstwa.

Powszechnie uznaje się, że w rodzinie mogą być stworzone najlepsze warunki dla rozwoju jej członków. Tutaj rozpoczyna się proces socjalizacyjno-wychowawczy, jeden z najistotniejszych aspektów wpływających na sposób funkcjonowania osoby w rodzinie

6 F. Adamski, Rodzina. Wymiar społeczno-kulturowy, Kraków 2002, s. 32. 
i w społeczeństwie. Podłożem tych działań, zarówno zamierzonych, jak ma to miejsce w procesie wychowawczym, oraz tych spontanicznych, jest system wartości społecznych. W obrębie prawa rodzinnego nie można pominąć więc aspektu aksjologicznego, który wypływa z kultury danego społeczeństwa, zatem chrześcijaństwo, silnie związane z kulturą narodu polskiego, będzie przenikało wychowanie dziecka.

Państwo dostrzega aspekt i znaczenie wychowania według własnych przekonań rodziców - zostało to wyrażone w art. 48 oraz w art. 53 ust. 3 Ustawy zasadniczej: „Rodzice mają prawo do zapewnienia dzieciom wychowania i nauczania moralnego i religijnego zgodnie ze swoimi przekonaniami”. Proces wychowawczy, jak pokazują liczne teorie pedagogiczne, zawsze opiera się na określonych wartościach. W konkordacie ${ }^{8}$ podpisanym z Rzeczpospolitą Polską Kościół katolicki w trosce o swoich wiernych ugruntował prawo do katolickiego wychowania dzieci (art. 12). Respektowanie wartości chrześcijańskich w zakresie nauczania i wychowania zostało wyrażone także we wstępie do ustawy o systemie oświaty9. Wydaje się zatem uprawnione założenie, że jeśli ustawodawca używa słowa „wychowanie”, w odniesieniu do katolików będzie ono w domyśle zawierało przydawkę „katolickie”, będzie odzwierciedlało system wartości rodziny.

Należy podkreślić, że rodzina wyznaniowa realizuje funkcję religijną, która wpisuje się w całościowy proces socjalizacyjno-

7 Konstytucja Rzeczypospolitej Polskiej z dnia 2 kwietnia1997 r. (Dz.U. Nr 78, poz. 483 z późn. zm. i sprostowaniem).

8 Konkordat między Stolicą Apostolską i Rzecząpospolitą Polską, podpisany w Warszawie 28 lipca 1993 r. (Dz.U. z 1998 r. Nr 51, poz. 318).

9 Ustawa z dnia 7 września 1991 r. o systemie oświaty (Dz.U. Nr 95, poz. 425 z późn. zm.). 
-wychowawczy. Jej zadaniem jest budowanie zasobów dziecka, takich jak „świadomość religijna, uczucia religijne, decyzje religijne, więź ze wspólnotą osób wierzących, praktyki religijne, moralność religijna, doświadczenie religijne i formy wyznania wiary" ${ }^{\prime \prime}$. Pomimo iż funkcje rodziny ulegają dużym przeobrażeniom na skutek dokonujących się zmian społecznych, w tym ingerujących w strukturę rodziny, i pomimo iż powstają instytucje wspierające rodzinę w jej zadaniach, to trudno zgodzić się z tym, by było możliwe zastąpienie rodziny w jej funkcji religijnej. Przemiany społeczne jednak sprawiły, że „funkcja religijna rodziny zupełnie zmieniła swoje dotychczasowe oblicze" - oznacza to, że sposób jej realizowania przez rodzinę będzie inny. Dotychczas religia podlegała transmisji międzypokoleniowej, rodzice edukowali dziecko w podstawowym zakresie wiary, dom był miejscem pierwszej katechezy, w drodze naśladownictwa przyjmowało ono określone zachowania religijne, podlegało zewnętrznej kontroli zachowań zgodnych z normami religijnymi, dorastało w atmosferze wiary ${ }^{11}$. Współcześnie mówi się o duchowości rodziny' ${ }^{12}$, wymiar wiary kierowany jest w jej wewnętrzne struktury. Nie bez znaczenia są zmiany funkcji wychowawczo-opiekuńczej, w której rodzice mają za zadanie kształtować osobowość dziecka; inne zadania, typu edukacja czy opieka, zostały w znacznej mierze przejęte przez takie instytucje jak szkoła czy przedszkole.

10 E. Rydz, Psychologia religijności/duchowości rodziny, [w:] Psychologia rodziny, red. I. Janicka, H. Liberska, Warszawa 2014, s. 208. Zob. dynamiczna poznawczo-rozwojowa strukturalna teoria rozwoju religijności Czesława Walesy, C. Walesa, Psychologiczna analiza rozwoju religijności człowieka ze szczególnym uwzględnieniem pierwszych okresów jego ontogenezy, [w:] Psychologia religii, red.

Z. Chlewiński, Lublin 1982, s. 144-179.

11 F. Adamski, Rodzina..., dz. cyt., s. 147.

12 E. Rydz, Psychologia religijności..., dz. cyt., s. 204-206. 


\section{Fizyczny i duchowy rozwój dziecka w perspektywie art. 96 § 1 k.r.o.}

Wychowanie potomstwa, jak wskazuje Kodeks rodzinny i opiekuńczy ${ }^{13}$, to jeden z atrybutów władzy rodzicielskiej. Władza ta przysługuje rodzicom dziecka i ma charakter niezbywalny, tylko w przypadku zagrożenia dobra dziecka może zostać ograniczona, zawieszona lub odebrana w drodze postępowania sądowego (art. 92, 107, 109-111 k.r.o.). Władza rodzicielska wygasa w sposób naturalny w wyniku śmierci podmiotu wychowującego lub wychowywanego oraz z chwilą ukończenia przez małoletniego 18 roku życia.

Ustawodawca w art. 96 § 1 k.r.o. stanowi: „Rodzice wychowują dziecko pozostające pod ich władzą rodzicielską i kierują nim. Obowiązani są troszczyć się o fizyczny i duchowy rozwój dziecka i przygotować je należycie do pracy dla dobra społeczeństwa, odpowiednio do jego uzdolnień". W normie tej ujęty został fizyczny i duchowy wymiar dziecka. Zauważa się w literaturze, że ustawodawca używa w tym artykule terminologii psychologiczno-pedagogicznej, a nie prawniczej ${ }^{14}$. Wydaje się, że adekwatnym byłoby zastosowanie w przepisie terminu „rozwój psychofizyczny”. Rozwój psychiczny nie jest tożsamy z rozwojem duchowym. Warto zatem poglądowo zaprezentować, w jaki sposób rozumiane są te sfery w obrębie doktryny i orzecznictwa sądowego.

Troska o fizyczny i duchowy rozwój dziecka to troska o jego dobro (art. 95 § 3 k.r.o.). Orzecznictwo sądowe odnosi się do realiów życia, poprzez obserwowane style zachowań rodzicielskich odwołuje się do ich przykładu, stosując w uzasadnieniach wyroków pouczenia, mające charakter motywujący do właściwego wypełniania

13 Ustawa dnia z 25 lutego 1964 r. Kodeks rodzinny i opiekuńczy (Dz.U. Nr 9, poz. 59 z późn. zm.) [dalej: k.r.o.].

14 T. Smyczyński, Prawo rodzinne i opiekuńcze, Warszawa 2012, s. 225. 
obowiązków. I tak współcześnie rodzice poświęcają swoim dzieciom „dużo czasu i uwagi, troszczą się o ich wychowanie i dobry rozwój. Rodzice karmią, pielęgnują, chronią, leczą, chodzą na spacery, uczą, bawią się i kochają swoje dziecko w każdym aspekcie, w każdym czasie i w każdym wymiarze, pomimo tego, że zwykle pracują i mają inne obowiązki”. Rodzice powinni uwzględniać potrzeby dziecka między innymi poprzez dawanie „poczucia miłości i poczucia bezpieczeństwa, jakie jest ważne dla rozwoju każdego dziecka, a zwłaszcza dziecka małego, które dopiero buduje swój świat”"

Istotą władzy rodzicielskiej jest wpajanie dziecku wzorców zachowania w zakresie moralnym, obyczajowym. Rodzice mają obowiązek nadzorowania i regulowania kontaktów dziecka z rówieśnikami, osobami bliskimi, sprawującymi funkcje wychowawcze. W zakresie pieczy nad dzieckiem istotna jest troska o jego bezpieczeństwo fizyczne, przed różnego rodzaju zagrożeniami, w tym używkami, uzależnieniem od komputerów, przemocą seksualną czy też sektami ${ }^{16}$. Smyczyński odwołuje się do współczesnej pedagogiki: „Wychowanie ma na względzie kształtowanie osobowości dziecka, w szczególności jego postaw emocjonalnych, światopoglądu i systemu wartości, obowiązkowości, umiejętności życia w rodzinie i poza nią". Rodzice powinni otoczyć dziecko miłością, aby mogło wzrastać w poczuciu bezpieczeństwa. Podkreśla się także znaczenie udziału obojga rodziców w wychowaniu dziecka; sąd poucza, że w wychowaniu dziecka ważna jest nie tylko matka - „każde normalne dziecko potrzebuje mieć ojca” ${ }^{17}$. „Rodzic

15 Sąd Rejonowy w Warszawie, postanowienie z 15.05.2014, VI Nsm 1187/13, http://orzeczenia.mst.warszawa.so.gov.pl/similardocs/\$N/154505250003012_VI_ Nsm_000549_2014_Uz_2014-07-22_001 (17.12.2014).

16 J. Strzebińczyk, Prawo rodzinne, Warszawa 2013, s. 258.

17 T. Smyczyński, Prawo rodzinne..., dz. cyt., s. 226. 
dobrze wykonujący swoją władzę dba o dziecko, dba o jego rozwój, o jego naukę, leczenie i dobre samopoczucie, zaspokaja wszystkie potrzeby dziecka w sposób adekwatny i uczy dziecko szacunku i dobrych relacji z innymi członkami rodziny, szkoły, ogólnie społeczeństwa"18. Wieloaspektowość wychowania dziecka nie została tu przedstawiona wyczerpująco, ale zwraca uwagę na zaspokajanie potrzeb dziecka wynikających z okresu rozwojowego, a także sytuacji społecznej.

Orzecznictwo i interpretacje prawne wydają się bezstronne w kwestii religii czy światopoglądu rodziców w zakresie wychowania. Jednak warto zwrócić uwagę, że w sytuacjach zmian w zakresie władzy rodzicielskiej pojawia się problematyka wychowania religijnego. W orzeczeniach sądu dotyczących regulacji kontaktów z dzieckiem wśród wyznaczanych terminów znajdują się święta Bożego Narodzenia czy Wielkanocy ${ }^{19}$, są to nieliczne odniesienia do wartości chrześcijańskich. Wychowanie religijne stanowi element troski o duchowy rozwój dziecka bez względu na konfesję i ten aspekt powinien być dostrzegany przez ustrojodawcę.

\section{Funkcja religijna w rodzinie katolickiej}

Kluczowe w tym miejscu jest określenie, na czym polega wychowanie katolickie. W Kodeksie prawa kanonicznego ${ }^{20}$ znajdujemy

18 Sąd Rejonowy w Warszawie, postanowienie z 29.05.2014, VI Nsm 773/13, http://orzeczenia.mst.warszawa.so.gov.pl/content/\$N/154505250003012_VI_ Nsm_000773_2013_Uz_2014-05-29_001 (17.12.2014).

19 Sąd Okręgowy w Sieradzu, postanowienie z 9.10.2013, I Ca 352/13, http:// orzeczenia.ms.gov.pl/content/\$N/152520000000503_I_Ca_ooo352_2013_ Uz_2013-10-09_001 (17.12.2014).

20 Codex Iuris Canonici auctoritate Ioannis Pauli PP. II promulgatus, 25.01.1983, „Acta Apostolicae Sedis” [dalej: AAS] 75 (1983), cz. II, s. 1-301; tekst 
legalną definicję wychowania katolickiego - jest ono nazwane „prawdziwym wychowaniem”, które „powinno objąć pełną formację osoby ludzkiej, zarówno w odniesieniu do celu ostatecznego, jak i w odniesieniu do dobra wspólnego społeczności, dlatego dzieci i młodzież tak winny być wychowywane, ażeby harmonijnie mogły rozwijać swoje przymioty fizyczne, moralne oraz intelektualne, zdobywać coraz doskonalszy zmysł odpowiedzialności, właściwie korzystać z wolności i przygotowywać się do czynnego udziału w życiu społecznym" (kan. 795 KPK). Norma ta wskazuje, że wychowanie katolickie jest procesem integralnego rozwoju człowieka, oznacza to, że każda płaszczyzna jest niezbędna dla chrześcijańskiego uformowania dziecka. Wiara wyznacza w wychowaniu zamysł działania, przez to nadaje mu określonego „ducha wychowania".

Kościół katolicki jest społecznością, której misją jest prowadzenie swoich członków do salus animarum. Człowiek realizuje zatem swoje ludzkie życie w pryzmacie wiary, z tego natomiast wynikają określone zadania rodziców katolickich wobec dzieci - „mają bardzo poważny obowiązek i prawo ich wychowania” (kan. 226 KPK). Wychowanie potomstwa wiąże się z odpowiedzialnością za jego socjalizację i wychowanie do życia ziemskiego, ale w szczególności dotyczy wprowadzenia do Kościoła i życia w Nim. Równocześnie, mówiąc o prawie rodziców do wychowania dzieci, nie można ominąć prawa dziecka do bycia wychowywanym, do „doskonalszego poznawania i miłowania Boga" (GE $\left.1^{21}\right)$.

łacińsko-polski: Kodeks prawa kanonicznego, przekład zatwierdzony przez Konferencję Episkopatu Polski, Poznań 1984 [dalej: KPK].

21 Sacrosanctum Concilium Oecumenicum Vaticanum II, Declaratio Gravissimum educationis de Educatione Christiana, 28.10.1965, AAS 58 (1966), s. 728-739; tekst łacińsko-polski, Sobór Watykański II, Deklaracja o wychowaniu 
Rodzice chrześcijańscy w pierwszej kolejności zobowiązani są do wprowadzenia swojego dziecka do wspólnoty Kościoła, tylko bowiem jako dziecko Boże może nabyć prawo do wychowania chrześcijańskiego (GE 2). Prawo kościelne nakłada na rodziców obowiązek zadbania o to, by chrzest ich dziecka odbył się możliwie jak najszybciej po urodzeniu, zaraz w pierwszych tygodniach. Nawet przed urodzeniem rodzice powinni udać się do proboszcza i poprosić o sakrament dla swojego dziecka (kan. 867 KPK). Sakrament jako znak łaski zakłada wiarę, w tym przypadku rodziców i rodziców chrzestnych, ale równocześnie daje dziecku jej wzrost $\mathrm{i}$ ją umacnia (59 $\mathrm{SC}^{22}$ ). Dlatego w trosce o dobro dziecka do godziwego ochrzczenia potrzebna jest uzasadniona nadzieja, że będzie ono wychowane po katolicku (kan. 868 § 1 pkt. 2 KPK).

Wraz z rozwojem dziecka po dojściu do używania rozumu, czyli osiągnięciu siódmego roku życia, rodzice są zobowiązani, by dzieci „zostały odpowiednio przygotowane i jak najszybciej posiliły się tym Bożym pokarmem, po uprzedniej sakramentalnej spowiedzi” (kan. 914 KPK). Sakramentem, który umacnia i doskonalej łączy osobę z Kościołem, ale także zobowiązuje do dawania świadectwa swoim życiem i słowem, jest bierzmowanie (kan. 879 KPK). Rodzicom powierzono troskę o to, by dzieci odpowiednio się do niego przygotowały i we właściwym czasie go przyjęły (kan. 890 KPK).

chrześcijańskim Gravissimum educationis, [w:] Sobór Watykański II, Konstytucje, dekrety, deklaracje, Poznań 1986, s. 484-505 [dalej: GE].

22 Sacrosanctum Concilium Oecumenicum Vaticanum II, Constitutio Sacrosanctum Concilium de Sacra Liturgia, 4.12.1963, AAS 56 (1964), s. 97-138; tekst łacińsko-polski: Sobór Watykański II, Konstytucja o liturgii świętej Sacrosanctum Concilium, [w:] Sobór Watykański II, Konstytucje, dekrety, deklaracje, Poznań 1986, s. 40-99. 
Normy kodeksu nakazują sposób realizacji wychowania dzieci, rodzice mają formować je w wierze i praktyce życia chrześcijańskiego, wychowanie religijne należy przede wszystkim do nich. W procesie tym bardzo ważną rolę odgrywa słowo i przykład rodziców, co zostało ujęte w samym przepisie prawnym (kan. 774 § 2 KPK). Sakramenty są elementarne dla życia duchowego dziecka, ale potrzebne jest stworzenie właściwego środowiska, aby mogło się ono rozwijać. Rodzice jako pierwsi katecheci wyjaśniają religijny sens wydarzeń takich jak przyjęcie sakramentów, święta liturgiczne, narodziny czy śmierć człowieka ${ }^{23}$. Powinni troszczyć się o powołanie swojego dziecka, szczególnie w jego duchowym wymiarze, przykładem swojego życia mogą torować „drogę szlachetności, zbawienia i świętości” (48 GS²4). Jeżeli dochodzi do „rozdziału między wiarą i życiem, między wiarą i nauką" konsekwencją jest moralność subiektywna, która jest przyczyną komplikowania sytuacji współczesnej rodziny ${ }^{25}$. Prawodawca wyznacza konkretne działania, które muszą być podjęte w ramach wychowania katolickiego.

23 Jan Paweł II, Adhortacja apostolska Ojca Świętego Jana Pawła II do biskupów kapłanów i wiernych całego Kościoła Katolickiego O katechizacji w naszych czasach, Warszawa 1980, s. 68.

24 Sacrosanctum Concilium Oecumenicum Vaticanum II, Constitutio pastoralis Gaudium et spes de Ecclesia in mundo huius temporis, 7.12.1965, AAS 58 (1966), s. 1025-1115; tekst łacińsko-polski: Sobór Watykański II, Konstytucja duszpasterska o Kościele w świecie współczesnym Gaudium et spes, [w:] Sobór Watykański II, Konstytucje, dekrety, deklaracje, Poznań 1986, s. 830-987 [dalej: GS].

25 C. S. Ilundáin, Konkluzja, Rodzina i jej obowiązki wychowawcze, [w:] W trosce o dobro małżeństwa i rodzin. Akta Międzynarodowego Kongresu Teologiczno-Pastoralnego z okazji I Światowego Spotkania Rodzin z Ojcem Świętym Rzym 6-8 października 1994 r., red. M. Brzeziński, Lublin 2011, s. 155. 


\section{Zaburzenie struktury rodziny}

Rodzina w cyklu życia zmienia się na poziomie strukturalnym, również jej funkcje ulegają wówczas naturalnym zmianom, istnieje zatem pomiędzy nimi ścisła zależność. Według prawa Kościoła katolickiego podstawą rodziny jest małżeństwo kanoniczne, które dla małżonków ochrzczonych jest sakramentem, czyli nierozerwalnym przymierzem kobiety i mężczyzny, którego jednym z celów jest zrodzenie i wychowanie potomstwa (kan. 1055, 1056 KPK). Zasadniczo formalnie struktura rodziny chrześcijańskiej może zostać naruszona wyłącznie w naturalny sposób, przez śmierć współmałżonka (kan. $1141 \mathrm{KPK}$ ). Jednym z wyjątków będzie sytuacja orzeczenia nieważności małżeństwa przez trybunał kościelny. Kodeks rodzinny określa, że ustanie małżeństwa następuje w wyniku śmierci współmałżonka oraz jeżeli pomiędzy małżonkami nastąpi zupełny i trwały rozkład pożycia (art. 55 i 56 k.r.o.). Funkcja wychowawcza, jaką wypełnia rodzina, ulega poważnej destrukcji i musi zostać przystosowana do nowej struktury rodziny przede wszystkim związanej z jej fizycznym podziałem.

\subsection{Kościół katolicki o prawach do wychowania dziecka rozwiedzionych rodziców}

Kodeks prawa kanonicznego zawiera kanony, które normują sytuację wychowania dziecka w przypadku, gdy małżeństwo rodziców zostało nieważnie zawarte, po wcześniejszym orzeczeniu rozwodu. W wyroku trybunału kościelnego strony powinny zostać pouczone o zobowiązaniach moralnych i cywilnych wynikających wobec wspólnych dzieci (kan. 1689 KPK), dotyczą one wymiaru materialnego, czyli utrzymania dziecka, w tym realizowania świadczeń alimentacyjnych, utrzymywania kontaktu oraz uczestniczenia w ich wychowaniu. „Wydaje się, że prawodawca chce uzmysłowić stronom, iż działanie sądu kościelnego wydającego wyrok stwierdzający nieważność małżeństwa nie jest realizacją procedury rozwodowej 
i nie stanowi zobowiązania do zniszczenia wszystkiego, co miało miejsce w przeszłości stron i ich potomstwa" ${ }^{26}$.

Znaczenie tego obowiązku zostało podkreślone klauzulą zawartą w kan. 1071 KPK, która zakazuje asystowania przy małżeństwie kanonicznym bez zezwolenia osobie, którą wiążą naturalne obowiązki wobec dzieci z poprzedniego związku. Za poprzedni związek rozumie się małżeństwo cywilne lub związek nieformalny. Ordynariusz miejsca może również czasowo zabronić zawarcia małżeństwa na skutek istniejącej i trwającej poważnej przyczyny (kan. 1077 §1 KPK). Do takich przyczyn zalicza się niewywiązywanie się z powyższych obowiązków. Są to instrumenty ochraniające prawa dziecka, stanowią mobilizację i zachętę do podjęcia troski o swoje potomstwo, jednak rażące zaniedbania w zakresie odpowiedzialności rodzicielskiej mogą stanowić przyczynek co do zdolności osoby do pełnienia istotnych obowiązków małżeńskich ${ }^{27}$. Dotyczą one sytuacji, gdy strona mająca obowiązki wobec potomstwa zmierza do zawarcia małżeństwa w Kościele ${ }^{28}$.

W literaturze kanonistycznej dostrzega się aspekt wychowania katolickiego dzieci w sytuacjach nieregularnych, takich jak rozpad małżeństwa przez rozwód czy separację; równocześnie nie wyklucza się, że rodzice mimo swej sytuacji chcą wychować potomstwo w wierze katolickiej ${ }^{29}$. Potwierdzeniem tego są motywy osób zaskarżają-

26 W. Wenz, Decyzja sędziego, [w:] Komentarz do Instrukcji procesowej „Dignitas Conubii”, red. T. Rozkrut, Sandomierz 2007, s. 339.

27 M. S. Foster, Divorce and remarriage: what about the children? Canons 1071, 1077, 1684, 1685, 1689, „Studia Canonica” 31 (1997), s. 147-191.

28 Zob. szerzej P. Majer, Zawarcie małżeństwa kanonicznego a obowiq̨zki naturalne wynikające z poprzedniego związku, „Annales Canonici” 4 (2008), s. 63-81.

29 P. Kroczek, Wychowanie: optyka prawa polskiego i prawa kanonicznego, Kraków 2013, s. 91. 
cych swoje małżeństwo przed sądem kościelnym, często żyjących w nowych związkach cywilnych: pragnienie wychowania dziecka zgodnie z wiarą, bycie dla niego przykładem w życiu religijnym, zbliżająca się Pierwsza Komunia Święta dziecka podnoszą świadomość życia religijnego rodziców, co mobilizuje do podjęcia próby sprawdzenia, czy małżeństwo było ważnie zawarte, czy też nie ${ }^{30}$. Wynika z tego, że istnieje potrzeba podjęcia działań, które sprzyjałyby wychowaniu katolickiemu dziecka w rodzinie rozwiedzionej.

\subsection{Władza rodzicielska a ustalenie kontaktów w sytuacji rozwodu małżonków}

Obligatoryjnie podczas orzeczenia wyroku rozwodowego następuje względem małoletnich dzieci małżonków uregulowanie sposobu sprawowania władzy rodzicielskiej, a także ustalenie kontaktów rodziców z dzieckiem (art. 58 k.r.o.). Czynności te wynikają ze szczególnej sytuacji, jaką jest faktyczne rozdzielenie małżonków, i mają chronić dziecko przed konfliktami mogącymi powstać pomiędzy małżonkami w odniesieniu do potomstwa. Przydzielenie uprawnień każdemu z rodziców zwykle wiąże się z powierzeniem opieki i władzy rodzicielskiej nad dzieckiem jednemu z nich oraz pozostawieniem niektórych atrybutów władzy rodzicielskiej drugiemu rodzicowi. Uprawnienia te zostają nadane przez sąd i mogą dotyczyć na przykład prawa współdecydowania w istotnych sprawach dziecka, w szczególności związanych z leczeniem, kształceniem i wyborem zawodu czy organizacją wypoczynku; zakres władzy rodzicielskiej określany jest w ujęciu o dotychczasowe więzi między rodzicem a dzieckiem i uwzględnia jego dobro.

30 U. Miernik, Motywy osób zaskarżających matżeństwo przed sq̨dem kościelnym, Kraków 2012, rkps; zob. A. Mendonca, Promotion and protection of rights in the Church, „Philippine Cannonical Forum” 11 (2000), s. 31-59. 
Art. 113 k.r.o. wyraźnie rozdziela władzę rodzicielską od kontaktów rodzica z dzieckiem. Utrzymywanie kontaktów dziecka $\mathrm{z}$ rodzicem jest jednym z praw dziecka ${ }^{31}$, a w stosunku do rodzica jest jego obowiązkiem. Niezależność od władzy rodzicielskiej sprawia, że nawet wówczas, gdy rodzic został pozbawiony władzy rodzicielskiej (art. 111 k.r.o.), została ona zawieszona (art. 11o k.r.o.) czy też ograniczona, sąd nie może zakazać rodzicowi kontaktów z dzieckiem, chyba że wymaga tego dobro dziecka. Rodzaje i sposób kontaktów z dzieckiem zostały określone w art. 113 § 2 k.r.o., pod pojęciem przebywania z dzieckiem rozumie się odwiedziny, spotkania, zabieranie dziecka poza miejsce jego stałego pobytu. Rodzic może się kontaktować poprzez bezpośrednie porozumiewanie się, utrzymywanie korespondencji, korzystanie z innych środków porozumiewania się na odległość, w tym ze środków komunikacji elektronicznej. W doktrynie podkreśla się, że kontakty rodzica z dzieckiem zawierają się w prawie dziecka do życia w rodzinie, a także w prawie do bycia wychowywanym przez rodziców ${ }^{32}$. Ograniczenie relacji rodzicielskiej wyłącznie do kontaktów pomiędzy dzieckiem i rodzicami nie jest idealną sytuacją wychowawczą, ale sprzyja budowaniu i podtrzymywaniu więzi rodzinnych.

Rodzice mogą utrzymać wspólną władzę rodzicielską, jeżeli przedstawią sądowi zgodne porozumienie o sposobie wykonywania władzy rodzicielskiej i utrzymywaniu kontaktów z dzieckiem, przy czym musi istnieć zasadne oczekiwanie, że będą współdziałać w sprawach dziecka (art. 107 § 2 k.r.o.). Wątpliwości budzi jednak

31 Konwencja o prawach dziecka przyjęta przez Zgromadzenie Ogólne Narodów Zjednoczonych 20.11.1989 (Dz.U. z 1991 r. Nr 120, poz. 526), art. 9; K. Gromek, Art. 113, [w:] K. Gromek, Kodeks rodzinny i opiekuńczy. Komentarz, Warszawa 2013.

32 T. Smyczyński, Prawo rodzinne..., dz. cyt., s. 255. 
brak precyzji w określeniu, jakie obszary to porozumienie powinno regulować, jakimi kryteriami należy się kierować, by nie naruszyć dobra dziecka. Postuluje się opracowanie aktów wykonawczych odnośnie do porozumienia. Forma ta niesie ze sobą duże możliwości, istnieją w literaturze propozycje opracowania gotowego formularza „porozumienia rodzicielskiego” czy też „planu wychowawczego", który uwzględnia różne aspekty wychowania dziecka, w tym religijne, wyraźnie pomijane w samym orzecznictwie. Podnosi się jednak kwestię stworzenia przez ustawodawcę pozornej sytuacji równouprawnienia rodziców sprawujących wspólnie władzę rodzicielską, gdyż rodzic, z którym dziecko nie przebywa, z natury ma ograniczony z nim kontakt 33 . Tym samym ma mniejszy wpływ na jego wychowanie, które odbywa się toku życia codziennego.

\section{Wnioski}

Wychowanie religijne-katolickie w rodzinie rozwiedzionej pozornie zawiera w sobie sprzeczności. W prawie Kościoła katolickiego obowiązek i prawo wychowania potomstwa nie ulega zmianom w przypadku, gdy rodzice podejmują decyzję o rozwodzie cywilnym. Małżeństwo kanoniczne nadal trwa, choć faktycznie małżonkowie są rozdzieleni. Kościół wykazuje troskę o ochronę dziecka, gdy małżeństwo rodziców zostaje uznane za nieważnie zawarte, a oni sami chcą zawrzeć nowe małżeństwo kanoniczne. Drogą do prawnego zabezpieczenia dobra dziecka, jego prawa do wychowania katolickiego będzie uregulowanie sytuacji kościelno-prawnej małżeństwa rodziców. Należy zatem na płaszczyznę prawa partykularnego skierować postulaty o poszerzenie dostępności do konsultacji prawnokanonicznych dla rozwiedzionych matżonków. Równocześnie na płaszczyźnie duszpasterskiej powstaje

33 J. Strzebińczyk, Prawo rodzinne..., dz. cyt., s. 173. 
konieczność zaktywizowania przekazu o odpowiedzialności rodziców, bez względu na ich sytuację cywilnoprawną, za wychowanie chrześcijańskie swojego potomstwa.

Powyższa analiza sytuacji wychowawczej dziecka rozwiedzionych rodziców przedstawiła trudność, jaka powstaje w wyniku zmiany w zakresie sprawowania władzy rodzicielskiej oraz opieki nad dzieckiem a możliwościami wychowania religijnego. Ustawodawca nakazuje rodzicom troskę o duchowy i fizyczny rozwój dziecka, doktryna oraz orzecznictwo dokonują pewnego redukcjonizmu, koncentrując się na fizycznym lub psychicznym rozwoju dziecka. Jeżeli jednym z praw i wolności obywatela jest jego wyznanie religijne, to w rzeczy samej będzie ono zawierało w sobie element duchowego rozwoju. Należy uznać, że jeśli ustawodawca używa określonej semantyki w normie prawnej, zamiar ten jest działaniem zamierzonym. Czy można zatem wymagać uwzględnienia w orzecznictwie takich kwestii jak konieczność ustalania przez rodziców kwestii praktyk religijnych dzieci, na przykład sakramentów? Wydaje się, że tak.

\section{SUMMARY}

\section{Religious education of children in situation of a diverse of their parents}

The paper presents relations between the norms of the Polish law and the church law regulating the education and upbringing of children in situation of the termination of marriage by divorce. One of the consequences of the divorce is disorder in the structure of the family. It can cause malfunction in realization of the educational function of the parents. In this context religious education can be in great danger. The civil regulations can, for instance by admitting full parental authority to one of the parents, 
reduce or even close the possibility of exercising the right of religious education of second of the parents. This situation is in conflict with the religious law that gave the right in question to the both parents. The Church has the means, also the legal ones that can be of help in protection of the good of the children in this matter. They are used most often in situation of the annulment of the marriage of the parents and also when a new marriage (even only civil one) or quasi marriage is contracted. The law requires to pay attention to the future religious education of the children.

Keywords: religious education, parental authority, divorce

Urszula Miernik, Religijne wychowanie dziecka w sytuacji rozwodu rodziców, [w:] Prawa dziecka: perspektywa Kościoła, red. ks. Piotr Kroczek, Kraków 2015, s. 135-151 (Annales Canonici Monographiae, 3). 